\title{
Tau Tau dalam Ritual Tradisi Maccera Manurung di Desa Pasang Kabupaten Enrekang
}

\author{
Suherman ${ }^{1}$, Mulyadi $^{2}$ \\ ${ }^{1}$ (Program Studi PGSD, FKIP, Universitas Muhammadiyah Enrekang, Indonesia) \\ ${ }^{2}$ (Program Studi BK, FKIP, Universitas Muhammadiyah Enrekang, Indonesia) \\ * Corresponding Author. E-mail: ${ }^{1}$ suhermankasumba@gmail.com
}

\begin{tabular}{|l|l|l|}
\hline Receive: 12/10/2020 & Accepted: 19/10/2020 & Published: 28/10/2020
\end{tabular}

\begin{abstract}
Abstrak
Ritual tradisi Maccera Manurung merupakan budaya tradisi yang sampai saat ini masih eksis di Desa Pasang, yang sekaligus merupakan identitas kultural etnis Massenrempulu. Dalam tradisi Maccera Manurung khusunya di Desa Pasang, terdapat kesenian Tau Tau yang membuat tradisi Maccera Manurung di Desa Pasang berbeda dengan tradisi Maccera Manurung di daerah/wilayah lain yang menyelenggarakannya. Penelitian ini mengkaji kesenian Tau Tau dalam tradisi Maccera Manurung di Desa Pasang tersebut sebagai salah satu jenis kesenian ritual tradisi, yakni dari segi urgensi dan fungsinya.Penelitian ini merupakan penelitian kualitatif dengan teknik pengumpulan data berupa observasi, wawancara, dan dokumentasi.Teknik pengabsahan data yang digunakan adalah triangulasi, dengan teknik analisis model interaktif. Adapun Hasil dari penelitian ini menunjukkan bahwa: 1). Kesenian Tau Tau dalam ritual tradisi Maccera Manurung di Desa Pasang sangat penting dan urgen karena merupakan pelengkap ritual, yakni sebagai personifikasi To Manurung; 2) Kesenian Tau Tau dalam ritual tradisi Maccera Manurung di Desa Pasang memiliki beberapa fungsi, antara lain: sebagai alat atau sarana ritual, sebagai sarana pemenuhan kebutuhan spiritual-religius warga masyarakat Desa Pasang, sebagai sarana ekspresi ekspresi pengalaman spiritual-religius warga masyarakat Desa Pasang, dan sebagai pedoman dalam beraktifitas atau pola perilaku masyarakat Desa Pasang secara kolektif.
\end{abstract}

Kata Kunci:Tau Tau, Seni Ritual, Maccera Manurung, Desa Pasang

\begin{abstract}
Maccera Manurung tradition ritual is a traditional culture that still exists today in the village of Pasang, as well as the ethnic identity of Massenrempulu. In the Maccera Manurung tradition, especially in the village of Pasang, there is the art of Tau Tau which makes the Maccera Manurung tradition in the village of Pasang different from the traditions of Maccera Manurung in other regions/regions that hold it. This research examines the art of Tau Tau in the Maccera Manurung tradition ritual in the village of Pasang as one of the traditional ritual arts, namely in terms of urgency and function. This research is a qualitative research using data techniques such as observation, interview, and documentation. The data validation technique used is triangulation, with an interactive model analysis technique. The results of this study indicate that: 1). Tau Tau art in the Maccera Manurung tradition ritual in the village of Pasang is very important and urgent because it is a complement to the ritual, namely as the personification of To Manurung; 2) The Tau Tau art in the Maccera Manurung tradition ritual in the village of Pasang has several functions, including: as a means or means of rituals, as a means of fulfilling the spiritual-religious needs of the village community, as a means of expression of spiritual-religious experiences of the residents of the village community, and as new in the activities or behavior patterns of the village people collectively.
\end{abstract}




\section{Pendahuluan}

Desa Pasang merupakan salah satu desa yang terdapat di Kecamatan Maiwa, Kabupaten Enrekang, Sulawesi Selatan. Selain dikenal sebagai 'surga' bagi burung bangau (Chandra, 2016), Pasang juga dikenal sebagai desa yang mampu mempertahankan dan melestarikan budayabudaya tradisi sebagai aset bangsa yang memiliki nilai Adiluhung.Salah satu kebudayaan tradisi (ritual tradisi) yang sampai saat ini masih eksis di Desa Pasang, yang sekaligus menjadi identitas kultural etnis Massenrempulu adalah ritual tradisi Maccera Manurung.

Secara umum, ritual tradisi Maccera Manurung dapat dikategorikan sebagai salah satu upacara ritual dalam konteks religi. Menurut Lestari (2015:8) Maccera Manurung merupakan serangkaian aktivitas atau pelaksanaan berupa penyembelian hewan dalam rangka memperingati kehadiran To Manurung, dan sekaligus sebagai rasa syukur masyarakat terhadap Tuhan Yang Maha Esa atas limpahan reskiNya.

Dalam ritual tradisi Maccera Manurung di Desa Pasang juga terdapat beberapa jenis kesenian yang kerap ditampilkan.Jenis-jenis kesenian yang tergolong ke dalam jenis kesenian ritual tradisi tersebut tentunya memiliki urgensi dan fungsi kultural tersendiri bagi masyarakat pendukungnya. Salah satu diantaranya, yang kemudian menjadi objek yang akan dikaji dalam penelitian ini adalah Tau Tau.

Tau Tau di Desa Pasang memiliki keunikan tersendiri, sebagaimana menurut keterangan salah satu warga masyarakat Desa Pasang bahwa Tau Tau tersebut sudah berusia ratusan tahun dan tidak pernah dicuci dengan menggunakan air. Tau Tau tersebut disimpan di tempat khusus, dan hanya dapat dikeluarkan saat dilaksanakan ritual Maccera Manurung.Sebagai personifikasi leluhur masyarakat adat Desa Pasang, Tau Tau tersebut juga memiliki unsur anatomi yang lengkap, yang terdiri dari kepala, tangan, badan (torso), dan kaki.Akan tertapi jika ditelaah dari bentuk visualisasinya, Tau Tau tersebut sangat kaku dan tidak profosional, serta ukuran tingginya yang hanya berkisar $80-90 \mathrm{~cm}$.

Keunikan lain dari Tau Tau dalam tradisi Maccera Manurung di Desa Pasang, yakni dari beberapa wilayah di Kabupaten Enrekang yang kerap menyelenggarakan tradisi Maccera Manurung, seperti Kaluppini dan Matakali, hanya tradisi Maccera Manurung di Desa Pasang yang di dalamnya terdapat kesenian Tau Tau. Tentunya, kesenian Tau Tau dalam tradisi Maccera Manurung di Desa Pasang tersebut tidak hadir begitu saja, melainkan ada alasan-alasan tersendiri yang menjadi dasar atau model arketipe primordialnya.Sebagaimana menurut Sumardjo (2010:113) bahwa dalam ritual tradisi religi, seni tidak boleh ditampilkan jika tidak memiliki maksud dan tujuan untuk ritual itu sendiri.

Berdasarkan uraian di atas, maka penelitian ini bertujuan mengkaji kesenian Tau Tau dalam ritual tradisi Maccera Manurung di Desa Pasang, yakni dari segi urgensi dan fungsinya. Penelitian ini penting dilakukan, mengingat, belum ada penelitian sebelumnya yang fokus membahas dan mengkaji secara khusus terkait Tau Tau dalam tradisi Maccera Manurung di Desa Pasang tersebut, apalagi dari segi urgensi dan fungsinya. Adapun beberapa penelitian terdahulu, kebanyakan lebih fokus membahas dan mengkaji persoalan-persoalan yang berkaitan dengan tradisi Maccera Manurung.Dan dengan demikian, dapat dikatakan bahwa penelitian ini memiliki tingkat originalitas yang dapat diperanggungjawabkan secara intelektual.

Sekiranya, penelitian ini dapat bermanfaat secara teoritis sebagai 
perangkat analisis persoalan yang berkaitan dengan kebudayaan secara umum, dan kesenian tradisi secara khusus.Di samping itu, hasil penelitian ini dapat bermanfaat secara praktis untuk dijadikan sebagai dokumen tentang budaya tradisi Desa Pasang secara khusus, dan Nusantara secara umum.

\section{Metode}

Penelitian ini merupakan jenis penelitian kualitatif, dengan menitikberatkan pada keutuhan fenomenafenomena objek yang diteliti (Endraswara, 2012:16), yaitu kesenian Tau Tau dalam ritual tradisi Maccera Manurung di Desa Pasang Kabupaten Enrekang.Daerah/wilayah yang menjadi lokasi dalam penelitian ini adalah Desa Pasang, Kecamatan Maiwa, Kabupaten Enrekang, Provinsi Sulawesi Selatan. Penentuan lokasi dalam penelitian ini disesuaikan dengan objek penelitian, di mana objek yang akan diteliti yaitu Tau Tau dalam tradisi Maccera Manurung hanya terdapat di lokasi tersebut.

Teknik yang akan digunakan untuk mengumpulkan data dalam penelitian ini, berupa: 1) Observasi, yakni mendatangi lokasi penelitian dan mengamati secara langsung Tau Tau dan prosesi ritual Maccera Manurung di Desa Pasang; 2) Wawancara, yakni mewawancarai secara mendalam beberapa narasumber atau informan yang memiliki pengetahuan terkait Tau Tau dan ritual Maccera Manurung di Desa Pasang; dan 3) Dokumentasi/studi dokumen, yakni mengumpulkan data berupa foto, video, dan dokumen-dokumen lainnya, termasuk literatur-literatur yang berkaitan dengan Tau Tau dan ritual Maccera Manurung di Desa Pasang. Khusus untuk studi dokumen, dilakukan dengan berbagai pertimbangan, seperti ketepatan data sesuai dengan masalah yang dikaji, memiliki tingkat kepercayaan yang tinggi, menghindari distorsi, serta telah mendapat izin dari pemilik data yang digunakan.
Untuk menjaga keabsahan data, digunakan teknik triangulasi (triangulation), yaitu teknik pemeriksaan keabsahan data dengan melihat gejala dari berbagai sudut pandang dan melakukan pengujian temuan dengan membandingkan data dari berbagai sumber (Hadi, 2006:77). Dalam hal ini, data yang diperoleh dari berbagai sumber selanjutnya akan dideskripsikan, dikategorikan, dan dianalisis.

Kemudian, teknik analisis data yang digunakan dalam penelitian ini merujuk pada teknik analisis data model interaktif yang diajukan oleh Miles dan Haberman (Rohidi, 2011:240), yaitu reduksi data, penyajian data, dan penarikan simpulan/verifikasi.

\section{Hasil dan Pembahasan}

\section{Gambaran Umum Desa Pasang}

Di awal telah disinggung sekilas tentang Desa Pasang, di mana Desa Pasang sendiri merupakan salah satu Desa yang ada di Kabupaten Enrekang, tepatnya di Kecamatan Maiwa, sekitar 12 KM dari pusat Kota Enrekang.Perjalanan menuju ke Desa Pasang sendiri dapat ditempuh dengan menggunakan kendaraan roda dua maupun roda empat. Walaupun pada beberapa titik masih terdapat jalanan yang jelek atau rusak, dapat dikatakan bahwa kondisi jalan secara keseluruhan dari Kota Enrekang samapai ke Desa Pasang cukup baik, karena sidah dilakukan pengaspalan dan pengecoran (beton) jalan menuju Desa tersebut. Desa Pasang sendiri berbatasan dengan wilayah Kecamatan Enrekang di sebelah barat, Desa Palahta di sebelah selatan, Desa Paladang di sebelah timur, dan Desa Pasai di sebelah utara.

Menurut Rustan Arsyad (Kepala Desa Pasang), sebelumnya Desa Pasang mencakup beberapa wilayah, diantaranya adalah Palakka, Limbuang, dan Paladang. Hal tersebut juga diterangkan dalam situs resmi Wikipedia bahwasebelum dilakukan pemekaran administratif, Desa Pasang mencakup wilayah-wilayah seperti Palakka, Limbuang, termasuk Paladang.Artinya, 
walaupun saat ini ketiga wilayah tersebut sudah terpisah secara administratif menjadi Desa, namun dalam hal identitas kultural ketiganya masih dalam satu rumpun keluarga.Hal tersebut dapat dilihat atau ditandai dengan adanya kesamaan dari segi ritual-ritual tradisi (adat) yang hidup dan berkembang dalam kehidupan sosial budaya masyarakatnya.

Kemudian, Desa Pasang secara garis besar memiliki kondisi fisik lingkungan berupa pegunungan (bukit-bukit).Luas wilayahnya (merujuk pada data statistik pembagian wilayah adat) sekitar 2.464 ha, dengan jumlah kepadatan penduduk yang mencapai angka 902 (473 laki-laki dan 429 perempuan), yang terdiri dari 211 kepala keluarga (dirujuk dari Data Statistik Badan Registrasi Wilayah Adat Desa Pasang).Adapun mata pencaharian utama warga masyarakat Desa Pasang adalah bertani. Selain itu, sebagaimana disampaikan oleh Rustan Arsyad (Kepala Desa Pasang) saat wawancara dengan peneliti bahwa ada juga masyarakat Desa Pasang yang bekerja sebagai pegawai negeri, honorer, dan ada pula yang bekerja sebagai pegawai atau honorer sambil bertani/berkebun.

\section{Ritual Tradisi Maccera Manurung di Desa Pasang}

Istilah Maccera Manurung terbagi atas dua suku kata, yaitu Maccera yang berarti "memotong hewan pada pelaksanaan upacara adat", dan Manurung yang berarti "orang yang turun dari kerajaan".Dengan demikian, Maccera Manurung dapat diartikan sebagai upacara adat dengan pemotongan hewan ternak untuk memperingati jasa-jasa To Manurung dan rasa syukur kepada Allah SWT (Dahyar, 2016:24; Hamid, dkk., 1998:14).Hal tersebut senada dengan asumsi yang diajukan oleh Hamsir dkk. (2017:432), bahwa istilah Maccera Manurung terdiri dari dua suku kata yaitu Maccera yang berarti "mendarah" atau "meneteskan darah" dan Manurung yang disepadankan dengan kata To Manurung, yang berarti "orang yang berasal atau turun dari tempat yang tinggi/kahyangan dengan sifat-sifat khusus yang melekat pada dirinya.

Ritual tradisi Maccera Manurung di Kabupaten Enrekang tidak hanya dilaksanakan di Desa Pasang saja, melainkan masih ada beberapa desa tetangga yang kerap melaksanakannya, seperti Kaluppini, Simbuang, dan Matakali, yang notabene menurut Usman (warga masyarakat Desa Pasang), tidak lain merupakan rumpun keluarga dari Desa Pasang itu sendiri. Adapun yang membedakan antara upacara tradisi Maccera Manurung di Desa Pasang dengan yang dilakukan di desa-desa lainnya adalah dari segi waktu, prosesi, dan benda-benda pusaka (benda Manurung) yang digunakan sebagai peralatan atau properti simbolik dalam pelaksanaannya.

Dari segi waktu pelaksanaan misalnya, di mana khusus untuk tradisi Maccera Manurung di Desa Pasang, waktu pelaksanaan akbarnya dilakukan satu kali selama dua tahun (Nasrullah, 2013:33), dan jadwal pelaksanaannya pun hanya dapat dilakukan pada hari kamis dan jum'at setelah panen raya atau menjelang musim tanam. Kemudian dari segi benda-benda pusakanya yang disebut benda Manurung, yakni La'bo, Barang, Gandang, dan Tau Tau.

Menurut Muslimin (tokoh adat Desa Pasang) saat wawancara dengan peneliti, "sebenarnya inti dari ritual tradisi Maccera Manurung ini tidak lain adalah penyampaian pesan-pesan moral yang dibawa oleh To Manurung kepada warga masyarakat, dan sekaligus sebagai ungkapan rasa syukur dan permohonan do'a agar kita sebagai manusia selamat dan sukses dalam aktivitas sehari-hari.'

Lebih lanjut terkait prosesi ritual tradisi Maccera Manurung di Desa Pasang, di mana dalam pelaksanaannya juga terdapat beberapa tahap.Adapun tahapannya, dimulai dengan kegiatan Maddoa' dan Mappadenddang, kegiatan Tudang Sipulung atar pemangku adat, serta 
pemotongan kerbau sebanyak dua ekor (betina dan jantan). Kemudian di sisi lain, para pemangku adat berkumpul di salah satu rumah tokoh adat Desa Pasang untuk menyiapkan sesaji dan mengeluarkan benda atau pusaka Manurung yang digunakan dalam prosesi ritual.

Tahap selanjutnya, di mana sesaji dan benda atau pusaka Manurung sudah disiapkan, maka para pemangku adat beserta warga masyarakat melakukan perjalanan napaktilas menuju puncak Buttu Pasang yang diyakini dan dipercayai oleh warga masyarakat Desa Pasang sebagai tempat peristirahatan terakhir leluhur mereka (To Manurung), yang terletak sekitar 5 KM dari Kampung Pasang. Dalam perjalanan napaktilas tersebut Tau Tau dan benda Manurung lainnya diarak dengan disertai tabuhan gendang (Gandang).

Setelah rombongan sampai dipuncak Buttu Pasang, maka kegiatan selanjutnya dalam ritual Maccera Manurung di Desa Pasang dilaksanakan. Dalam hal ini dilakukan kegiatan yang disebut Massajo', yakni berupa penyampaian atau memperdengarkan kembali pesan-pesan To Manurung di depan Tau Tau yang dijadikan sebagai simbol To Manurung, yang meliputi pesanpesan kebaikan seperti saling menghormati, saling menghargai, dan saling membantu, kepada warga masyarakat. Massajo' tersebut dilakukan oleh pemangku adat dengan gerakan ritmis tertentu, disertai dengan ayunan tangan yang memegang parang sambil membacakan Sajo'. Di sisi lain, juga dilakukan penyembelian hewan ternak berupa kambing.

Setelah rangkaian kegiatan ritual di Buttu Pasang selesai, maka para pemangku adat beserta rombongan bergegas meninggalkan Buttu Pasang dan kembali ke Kampung Pasang untuk melanjutkan kegiatan di rumah adat yang telah disiapkan. Adapun kegiatan yang dilaksanakan di rumah adat adalah kembali melakukan kegiatan Massajo'. Setelah ritual massajo', maka dilanjutkan dengan membaca doa yang dipimpin oleh petua adat bersama seluruh masyarkat adat. Kemudian di sisi lian juga kembali dilakaukan kegiatan Maddoa' dan Mappadendang sebagai kegiatan hiburan.Setelah seluruh rangkaian kegeiatan prosesi ritual selesai maka benda atau pusaka Manurung disimpan kembali di tempatnya masing-masing.Ritual tradisi Maccera Manurung ini dinyatakan selesai dengan dilaksanakannya makan bersama warga masyarakat, dengan makanan yang telah disiapkan berupa Sokko' dan daging kerbau.

\section{Urgensi Kesenian Tau Tau dalam Ritual Tradisi Maccera Manurung di Desa Pasang}

Terkait kesenian Tau Tau (selanjutnya disebut Tau Tau) yang menjadi objek kajian dalam penelitian ini, dapat dikatakan bahwa kesenian tersebut merupakan salah satu wujud kebudayaan warga masyarakat Desa Pasang. Jika merujuk pada konsep yang diajukan Koentjaraningrat (1985:2) tentang wujud kebudayaan, maka Tau Tau dalam ritual tradisi Maccera Manurung di Desa Pasang tersebut termasuk dalam kategori artefak kebudayaan, dalam hal ini artefak kebudayaan warga masyarakat Desa Pasang.

Kesenian Tau Tau sebagai salah satu benda puasaka (benda Manurung) dalam ritual Maccera Manurung di Desa Pasang dapat dikategorikan sebagai jenis kenesian ritual atau seni ritual.Hal tersebut demikian, karena jenis kesenian semacam ini merupakan jenis kesenian yang erat kaitannya dengan realitas transenden, dan hanya dihadirkan dalam hajatan tertentu atau yang berkaitan dengan religi (Sumardjo, 2010:111).Demikian halnya dengan Tau Tau di Desa Pasang, yang hanya dihadirkan dalam upacara atau ritual tradisi Maccera Manurung.

Selain menjadi salah satu pembeda dengan ritual Maccera Manurung di daerah lain, kesenian Tau Tau juga menempati posisi yang sangat penting dalam prosesi ritual atau upacara Maccera Manurung di 
Desa Pasang. Oleh karena itu, dapat dikatakan bahwa kehadiran kesenian Tau Tau tersebut dalam ritual tradisi Maccera Manurung di Desa Pasang sangatlah urgen.Adapun letak urgensinya dapat dilihat dari fenomena-fenomena berikut.

Pertama, sikap dan perlakuan warga masyarakat Desa Pasang yang sangat menghormati Tau Tau dalam prosesi ritual tradisi Maccera Manurung.Tau Tau tidak boleh diletakkan disembarang tempat, dan bahkan juga tidak boleh menyentuh tanah.Selain itu, posisi Tau Tau selalu lebih tinggi atau sejajar dengan kepala warga masyarakat.Diperkuat oleh asumsi Patarai (tokoh adat Desa Pasang) bahwa "kami sangat menghormati Tau Tau karena ia adalah gambaran ToManurung".Artinya, fenomena tersebut menunjukkan bahwa Tau Tau sangat urgen dalam ritual tradisi Maccera Manurung di Desa Pasang karena bukan merupakan benda biasa, melainkan benda yang bersifat sakral.

Kedua, sebagai properti atau peralatan upacara sakral, Tau Tau di Desa Pasang hanya dikeluarkan ketika upacara Maccera Manurung digelar, dan akan disimpan kembali bersama benda-benda Manurung lainnya di Banua saat upacara telah selesai. Patarai (tokoh adat Desa Pasang) memperkuat asumsi tersebut dengan mengatakan bahwa "Таu Tau itu tidak boleh dikeluarkan dari tempat penyimpanannya yang disebut Banua kalau tidak digelar ritual Maccera Manurung."Kiranya hal tersebut demikian karena Tau Tau merupakan benda yang sangat disakralkan oleh warga masyarakat Desa Pasang.

Ketiga, terpenting bahwa Tau Tau dalam ritual tradisi Maccera Manurung di Desa Pasang urgen karena merupakan salah satu peralatan upacara.Bahkan boleh dikata Tau Tau tersebut menjadi peralatan yang paling penting.Hal tersebut dapat dicermati dari asumsi salah satu warga masyarakat Desa Pasang, yang mengatakan bahwa "Tau Tau harus ada dan ikut dalam prosesi upacara, karena kalau tidak ada Tau Tau maka tidak ada gunanya digelar ritual
Maccera Manurung." Di sisi lain, sebagaimana diamati oleh peneliti bahwa boleh dikata Tau Tau tersebut merupakan peralatan atau properti upacara yang paling urgen atau paling penting dalam prosesi ritual Maccera Manurung di Desa Pasang karena Tau Tau dihadirkan dalam prosesi ritual Maccera Manurung di Desa Pasang dijadikan sebagai personifikasi leluhur masyarakat Desa Pasang itu sendiri. Artinya, Tau Tau menjadi simbol hadirnya To Manurung dalam prosesi ritual Maccera Manurung sehingga ritual tersebut menjadi bermakna bagi masyarakat Desa Pasang.Diperkuat kemudian oleh Patarai (tokoh adat Desa Pasang), bahwa "ya, Tau Tau tersebut adalah simbol leluhur kami." Kiranya, fenomena ini sekaligus mencerminkan ekspresi religius warga masyarakat Desa Pasang terhadap leluhur mereka yakni dalam bentuk simbol (simbolisasi), sebagaimana menurut Eliade bahwa pengenalan manusia atau masyarakat terhadap Yang Transender hanya dapat dilakukan melalui proses simbolisasi (Saliba, 1976:54; Suherman, 2017:168).

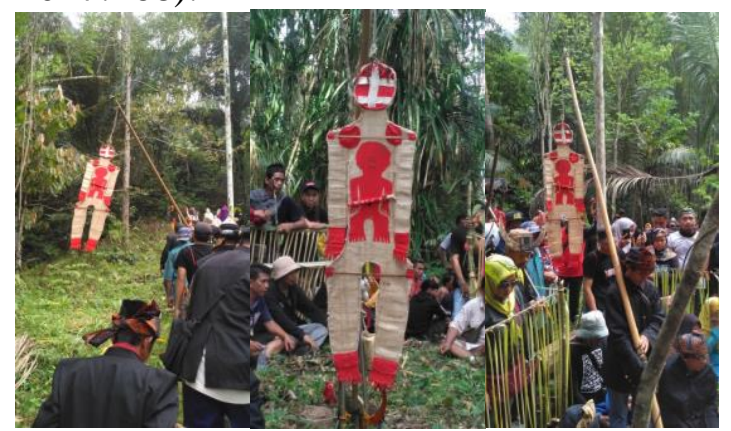

Tau Tau dalam ritual tradisi Maccera Manurung di Desa Pasang (Dokumentasi: Suherman)

\section{Fungsi Tau Tau dalam Ritual Tradisi Maccera Manurung di Desa Pasang}

Sebagai salah satu jenis kesenian yang tergolong kedalam jenis kesenian ritual, Tau Tau dalam ritual tradisi Maccera Manurung di Desa Pasang tentu memiliki fungsi tersendiri bagi ritual dan bagi warga masyarakat pendukungnya yakni warga masyarakat Desa Pasang. Adapun fungsi Tau Tau dalam ritual tradisi Maccera 
Manurung di desa pasang adalah sebagai berikut.

\section{a. Fungsi fisik/benda}

Sebagaimana telah diuraikan pada pembahasan terdahulu bahwa Tau Tau merupakan salah satu perlengkapan upacara atau ritual Maccera Manurung khususnya di Desa Pasang, maka kesenian tersebut memiliki fungsi fisik sebagai alat dan sarana ritual.Sebagai alat dan sarana ritual, Tau Tau tentu berbeda dengan benda-benda lainnya, dan juga tentu berbeda dengan jenis kesenian lainnya (benda dan kesenian biasa/profan).Hal tersebut demikian karena pada dasarnya Tau Tau di Desa Pasang merupakan jenis kenesian yang sakral, yang hanya hadir dalam ruang dan waktu yang sakral pula, yakni dalam prosesi ritual Maccera Manurung.Diperkuat oleh Lamappa (tokoh adat Desa Pasang) saat wawancara dengan peneliti bahwa "Tau Tau ini hanya dikeluarkan jika dilaksanakan ritual Maccera Manurung."

Di samping itu, fungsi fisik Tau Tau dalam ritual tradisi Maccera Manurung di Desa Pasang sebagai alat dan sarana ritual adalah dijadikan sebagai personifikasi To Manurung yang dipercayai dan diyakini oleh warga masyarakat Desa Pasang sebagai leluhur mereka. Dengan kata lain, Tau Tau dalam ritual Maccera Manurung dihadirkan sebagai gambaran atau perwujudan To Manurung warga masyarakat Desa Pasang. Dan oleh karena dikaitkan dengan makna personifikasi, maka Tau Tau tersebutjuga perlu dilihat sebagai perwujudan nilai-nilai abstrak yang tinggi, agung, kudus, atau transenden, yang melatarbelakangi keberadaannya. Terpenting di sini bahwa hal tersebut diwujudkan dalam bentuk simbol, karena memang pada hakikatnya, sebeagaimana dikatakan Mircea Eliade bahwa hanya melalui simbol manusia bisa sampai pada pengenalan terhadap sesuatu yang bersifat adikodrati (Suherman, dkk, 2017:169).

\section{b. Fungsi Spiritual-Religius}

Kesenian Tau Tau dalam ritual tradisi Maccera Manurung di Desa Pasang tercipta dari ide atau gagasan, atau dari pengalaman masyarakat Desa Pasang terkait To Manurung yang diyakini dan dipercayai oleh masyarakat Desa Pasang sebagai nenek moyang mereka. Oleh karena itu, Tau Tau tersebut sangat dijaga dan dihormati oleh warga masyarakat Desa Pasang yang meyakini dan mempercayainya, bahkan disakralkan seperti diterangkan di awal.

Jika ditinjau dari segi ide atau gagasan penciptaannya, maka dapat dikatakan bahwa kesenian Tau Tau dalam ritual tradisi Maccera Manurung di Desa Pasang tersebut hadir atau tercipta dari dorongan kebutuhan spiritual-religius warga masyarakat Desa Pasang. Hal tersebut sejalan dengan pendapan Soedarso (2006:119) bahwa karya seni yang diciptakan untuk memenuhi kebutuan spiritual manusia atau masyarakat memiliki keindahan yang berkaitan dengan pengalaman spiritual-religius manusia, terutama yang berkaitan dengan keyakinan dan kepercayaan terhadap kekuatankekuatan adikodrati. Diperkuat oleh Read (Suherman, 2017:78) yang mengatakan bahwa seni dan ritual dalam suatu kegiatan agama menjadi satu kesatuan yang akrab, karena memuat kegiatan pengalaman keimanan dan pengalaman estetik. Artinya, hal tersebut sekaligus menunjukkan bahwa Tau Tau dalam ritual tradisi Maccera Manurung di Desa Pasang berfungsi sebagai sarana pemenuhan kebutuhan spiritual-religius warga masyarakat Desa Pasang yang meyakini dan mempercayainya.

\section{c. Fungsi Ekspresi}

Pada dasarnya suatu karya seni merupakan suatu bentuk atau wujud ekspresi manusia.Demikian halnya dengan kesenian Tau Tau dalam ritual tradisi Maccera Manurung di Desa Pasang. Akan tetapi, lebih jauh terkait Tau Tau dalam ritual tradisi Maccera Manurung di Desa Pasang, di mana Tau Tau tersebut bukan 
hanya sekedar bentuk atau wujud ekspresi pengalaman estetik semata layaknya karya seni biasa (seni profan), melainkan dan yang paling utama adalah suatu bentuk atau wujud ekspresi pengalaman spiritualreligius warga masyarakat Desa Pasang.

Namun demikian, perlu dipahami bahwa pengalaman estetik di sini dapat membantu warga masyarakat Desa Pasang mencapai pengalaman religius dalam memaknai Tau Tau tersebut sebagai personifikasi leluhur mereka. Sebagaimana dikatakan Sumardjo (2000:325) bahwa pengalaman religius itu hanya dapat dicapai secara maksimal setelah proses pengalaman estetik selesai. Dengan dimikian, dapat pula dikatakan bahwa kesenian Tau Tau dalam ritual tradisi Maccera Manurung di Desa Pasang merupakan suatu bentuk atau wujud ekspresi warga masyarakat Desa Pasang yang memiliki nilai estetik dan religius, dan kedua nilai tersebut saling mendukung satu sama lain.

Lebih lanjut, di mana Tau Tau dalam ritual tradisi Maccera Manurung di Desa Pasang merupakan ekspresi atau visualisasi rasa rindu mendalam dan rasa syukur yang dialami masyarakat Desa Pasang terhadap leluhur mereka yakni To Manurung yang diyakini dan dipercayai sebagai panutan dan pemberi berkah. Rasa rindu dan rasa syukur yang mendalam itu diungkapkan oleh Lamappa (tokoh adat Desa Pasang) saat wawancara dengan peneliti dengan mengatakan bahwa "Tau Tau itu dibuat agar kami selalu ingat To Manurung kami...kalau kami melihat Tau Tau itu, kami merasa dekat dengan To Manurung. Kemudian dibuatkan upacara sebagai tanda rasa syukur kami atas berkah yang diberikan kepada kami”. Itulah sebabnya kesenian Tau Tau di Desa Pasang bukan hanya dianggap sebagai benda estetik semata, melainkan juga dihormati, disakralkan, dan bahkan disaat tertentu dijadikan sebagai objek pemujaan oleh masyarakat Desa Pasang, seperti dalam fenomena ritual tradisi Maccera Manurung. Singkatnya, Tau Tau dalam ritual tradisi Maccera Manurung di Desa Pasang juga berfungsi sebagai sarana ekspresi ekspresi pengalaman spiritualreligius warga masyarakat Desa Pasang.

\section{d. Fungsi Sosial Masyarakat}

Di awal telah diterangkan bahwa fungsi social masyarakat dari pada seni yakni berperan sebagai pedoman dalam beraktifitas atau pola perilaku masyarakat secara kolektif, dan juga sebagai penjelasan terkait aspek-aspek tentang eksistensi sosial. Dalam hal ini kesenian Tau Tau dalam ritual tradisi Maccera Manurung di Desa Pasang juga memiliki peran yang sangat penting bagi kehidupan sosial masyarakat Desa Pasang, terutama sebagai pedoman dalam beraktifitas atau pola perilaku masyarakat Desa Pasang secara kolektif. Hal tersebut dapat dilihat pada fenomena napaktilas dalam ritual Maccera Manurung di Desa Pasang, di mana Tau Tau yang dijadikan sebagai simbol To Manurung diarak oleh warga masyarakat secara bersamaan.Dalam fenomena prosesi ritual tersebut, Tau Tau yang diarak sangat dijaga dalam perjalanan napaktilas.Kemudian selama dalam perjalanan napaktilas, Таи Tau tidak boleh diletakkan di sembarang tempat dan posisinya selalu lebih tinggi di banding tinggi warga masyarakat.Apabila Tau Tau tersebut jatuh, maka warga masyarakat serentak mengambil dan mengembalikan Tau Tau ke posisi yang seharusnya.

Dari fenomena tersebut, dapat dikatakan bahwa Tau Tau dalam ritual tradisi Maccera Manurung menciptakan suasana yang harmonis antar warga masyarakat, karena dengan adanya Tau Tau tersebut warga masyarakat senantiasa menjaga keharmonisan dan integritas kolektif sebagai suatu kelompok masyarakat. Singkatnya, Tau Tau dalam ritual tradisi Maccera Manurung di Desa Pasang mampu meningkatkan solidaritas antar warga masyarakat.Kiranya hal tersebut sesuai dengan pendapat Rohendi (2016:63) yang mengatakan bahwa seni yang hadir dalam sebuah hajatan atau upacara yang melibatkan masyarakat 
memiliki peran penting untuk menyatukan warga masyarakat pendukungnya.

\section{Simpulan}

Berdasarkan hasil dan pembahasan yang telah diuraikan, maka dapat ditarik simpulan bahwa kesenian Таи Таи dalam ritual tradisi Maccera Manurung di Desa Pasang tidak hadir begitu saja tanpa alasan tertentu yang menjadi dasar penciptaannya. Dalam hal ini adalah urgensi dan fungsinya sebagai salah satu jenis kesenian ritual. Pertama, dari segi urgensinya, di mana kesenian Tau Tau dalam ritual tradisi Maccera Manurung di Desa Pasang sangat penting dan urgen karena merupakan pelengkap ritual, yakni sebagai personifikasi To Manurung. Kemudian yang kedua, yakni dari segi fungsinya, di mana kesenian Tau Tau dalam ritual tradisi Maccera Manurung di Desa Pasang memiliki beberapa fungsi, antara lain: sebagai alat atau sarana ritual, sebagai sarana pemenuhan kebutuhan spiritualreligius warga masyarakat Desa Pasang, sebagai sarana ekspresi ekspresi pengalaman spiritual-religius warga masyarakat Desa Pasang, dan sebagai pedoman dalam beraktifitas atau pola perilaku masyarakat Desa Pasang secara kolektif.

\section{Daftar Pustaka}

[1] Dahyar, M. C. (2016). Tradisi Maccerang Manurung di Desa Kaluppini Kabupaten Enrekang (Studi Kebudayaan Islam). Disertasi. Universitas Islam Negeri Alauddin Makassar.

[2] Endraswara, Suwardi. (2012). Metodologi Penelitian Kebudayaan. Yogyakarta: Gadjah Mada University Press.

[3] Hadi, Y. Sumandiyo, (2006), Seni dan Ritual Keagamaan, Yogyakarta: Penerbit Buku PUSTAKA.

[4] Hafid., Muh. Yunus, \& Nur Alam Shaleh, (1998). Bosara(media informasi sejarah danbudaya
Sulawesi Selatan), Cet I; Makassar: Depertemen Pendidikan dan Kebudayaan, Direktorat Jendral Kebudayaan, Balai Kajian dan NilaiTradisional Ujung Pandang.

[5] Koentjaraningrat. (1985).

Kebudayaan Mentalitet dan Pembangunan. Jakarta: PT. Gramedia.

[6] Lestari, Riska Ayu. (2015). Maccera To Manurung Pada Masyarakat Desa Pasang Kecamatan Maiwa Kabupaten Enrekang. Skripsi. Universitas Islam Negeri Alauddin Makassar.

[7] Nasrullah. (2013). Hubungan Pola Ritmik Permainan Bunyi Lesung dengan Gerak Permainannya Dalam Masyarakat Massenrempulu Enrekang. Skripsi. Universitas Negeri Makassar.

[8] Rahma, Nur., Hajra Yansa., \& Hamsir. TINJAUAN SOSIOKULTURAL MAKNA FILOSOFI TRADISI UPACARA ADAT MACCERA MANURUNG SEBAGAI ASET BUDAYA BANGSA YANG PERLU DILESTARIKAN (Desa Kaluppini Kabupaten Enrekang Sulawesi Selatan).

[9] Rohendi, H. (2016). Fungsi Pertunjukan Seni Reak Di Desa Cinunuk Kecamatan Cileunyi. JPKS: Jurnal Pendidikan dan Kajian Seni, 1(1), 54-65).

[10] Rohidi, Tjejep Rohendi, (2011), Metodologi Penelitian Seni, Semarang: Cipta Prima Nusantara.

[11] Saliba, Jhon A. (1976). Homo Religiosus in Mircea Eliade, An Anthropological Evaluation. Leiden: E.J. Brill.

[12] Soedarso. (2006). Trilogi Seni: Penciptaan, Eksistensi, dan Kegunaan Seni. Yogyakarta: ISI Yogyakarta.

[13] Suherman, S. (2017). Perwujudan dan Nilai Patung Tau-Tau Toraja Sulawesi Selatan. Pelataran Seni, 2(1), 77-92.

[14] Suherman, S. (2017). Perwujudan, Mitos, dan Nilai Karakter Patung Tau 
Tau di Toraja Sulawesi Selatan. Tesis. Universitas Negeri Semarang.

[15] Suherman, S., Triyanto, T., \& Sunarto, S. (2017). Embodiment, myth, and characters' value sculpture of Tau Tau at Toraja in South Sulawesi. Catharsis, 6(2), 161-173.

[16] Sumardjo, Jakob. (2000). Filsafat Seni. Bandung: ITB.

[17] Sumardjo, Jakob. (2010). Estetika Paradoks. Bandung: Sunan Ambu Press.

[18] Wahyu Chandra. (2016). "Desa Pasang, 'Surga' Burung bagi Bangau di Sulsel". Dalam https://www.mongabay.co.id/2016/05/ 23/desa-pasang-surga-bagi-burungbangau-di-sulsel/. Diakses 2019.

\section{Profil Penulis}

Suherman, lahir pada tanggal 29 september 1990. Sarjana Pendidikan Seni Rupa pada Program Studi Pendidikan Seni Rupa FKIP Universitas Muhammadiyah Makassar (selesai tahun 201).Magister Pendidikan Seni pada Program Studi Pendidikan Seni Pascasarjana Universitas Negeri Semarang (selesai tahun 2017).Saat ini mengabdi sebagai tenaga pengajar pada Program Studi Pendidikan Guru Sekolah Dasar FKIP Universitas Muhammadiyah Enrekang. 